\title{
REGULATION OF INDUSTRIAL CORPORATIONS
}

I.

A mighty power has been built up in this country in recent years that seems to fairly stagger the methods of our gorernment to maintain the equal rights of all the people. Something appears to be wrong with business interests generally, and the people are passing through a state of social unrest. The influence of financial men has become so powerful and far reaching in selfinterest that doubt is expressed whether its iron grip on government and business can ever be destroyed. This mighty power has crippled or destroged competition by placing a limitation in the field of production. It fixes the prices of finished products and raw materials and imposes its burdens upon the silent consuming public without restraint. The spirit of competition seems to have almost ranished, being superseded by extortion.

In finance this mighty power of influence is unlimited. The association of men engaged in numerous chamnels of business: regulates or controls credit. This power manipulates the volume of money by inflation or contraction recuired for the constant transaction of business of the entire country. Fabulou profits of business are made out of promotions and combinations. hy the acquisition of vast areas of the public domain and rapid monopolization of the natural resources of timber, coal and iron. Industries have been closed and business slackened in competing localities to stifle fair competition by this mighty power in illegal procedure of usurpation. Insteacl of living under the lofty principles of a mighty Constitution where the citizen is sovereign we are actually living under a form of government where criminal might is right. In transportation, after a prolonged struggle for government control, these public service corporations have been forced to discatd their most powerful competitive weapon-the rebate-and thus stop the old destructive competitive methods which had been practiced by the railroads to their own and the

Nore:-This is the third article of a series of three articles by J. Newton Baker, Esq., on the "Regulation of Industrial Corporations." The lirst article, concerning the American Federation of Labor, was published in the December issue of 1912; the second article, concerning the Fril of Special Privilege, was published in the Jamuary issue of 1913. 
public detriment. The systems of railroads were not destroyed, but some of the evils then existing in the railroad business were eradicated. All the wasteful, injuriotis methods of a score of years ago in transportation business were worthless and vicious conipetitive methods, but they have been virtually eliminated through Federal regulation. These railroads are only the domestic agencies of trade, and they have been regulated in a mantier that has produced beneficial results to the shipper and consuming public. So long as the regulation cloes not become warped the public may continttc to expect impartiality of service.

The public believes that all improper trust methods or practices may be divided into three classes, that is to say:

First: Attempted monopoly, or attempts to effectuate by agrecments or combinations of individuals, partnerships, or corporations, those results of monopoly for which it is condemned, viz., the fixing or arbitrary control of prices, or the limiting of output below actual public needs.

Second: Methods and practices by eitlier individuals, partnerships, or corporations toward competitors, of such character as to require in the public interest, prohibition, and punishment mder the law of criminal conspiracy.

Third: Excessive issuance of securities by corporations, resulting in abnormal and improper absorption of capital for speculative purposes alone and not for the purpose of increasing efficiency.

Combination is the distinctive characteristic of this commercial era. The tendency toward combination in other directions has passed through hardship similar to this combination of industry. Political, religious, educational, industrial and commercial history are similar in purpose. There is no difficulty in determining where consolidation is harmless and where it is perilous to the general public. The ruinous and unreasonable competition obviously conducted for the express purpose of suppressing competition should be prohibited from wielding tyrannical power. By a revival of competition there is a guaranty of reasonable prices not adduced by regulation but rather the result of economic forces by tolerant competition. If competition proves tolerant, it should be permitted, but if intolerant, a practical line must be drawn to prohibit certain things which naturally involve the intolerant kind of competition. Regardless of regulation, actual or potential. 
competition is impossible to be eradicated. Regulation would tend to eraclicate unfair competition and induce others to enter a free field. The business man of today must continually fight every foot of ground, or he will find by his inefficiency new industries will be established with surprising dexterity. Human nature is aggressive to competition, and ingenuity is extraordinary to grasp opportunities.

In political combinations we have seen the original thirteen colonies combine in a single nation of prosperity, foremost among the nations of the world. Even in Europe, dukedoms and principalities have combined into political unions of monarchies and kingdoms to more ably meet competitive conditions of commercial prosperity. The United Kingdom of Great Britain and Ireland. and its possessions and colonies scattered over the face of the globe, have become affiliated in a British Empire. This political amalgamation, or combination, is a movement toward more liberty than is possessed by indiviclual provinces. Those countries and peoples who once were dire foes are now the friends of liberty and friends of each other. Political world combination is not destructive to liberty, nor injurious to the general welfare. This political combination, based upon a spirit of voluntary coüperation, increases the general welfare with the inevitable result that this Lnited States is a world power having races: and religions combined.

In the industrial world we have the spirit of combination which is a world-wide movement. Labor unions have combined, and attempted to destroy capital and private property. Then political leaders have combined for political efficiency, religious leaders for religious efficiency; educational leaders for educational efficiency, labor leaders for labor efficiency, and lastly we have great combinations of commercial leaders and capital for commercial efficiency; so that the political, religious and educational conbinations are complete and beneficial, but the industrial and commercial combinations have yet to be properly organized. The remedy for our industrial and conmercial ills is not its destruction and disorganization, but rather its regulation.

II.

Much interest is taken in the operations and propriety of having industrial capital control and operate railroads as common 
carriers, if such controlled and operated railroads acting as common carriers are an essential part of the industrial operation. Some railroads are common carriers in the ordinary sense of the general term only. Other railroads are partly plant facilities but act as common carriers for actual transportation for other railroads, receiving a division of the rates for services rendered. Railroads of another class are plant facilities, better known as switching tracks, constructed exclusively for the efficient operation of the industry. By the incorporation of switching lines under the designation of common carriers associated with the operation of general trunk lines there appears to be hidden a great evil which has been most clifficult to detect. This ownership of industrial corporations by common carriers and by industrial corporations is frequently taken advantage of to defeat equality between shippers by an unreasonable clivision of point rates, forced upon the carriers by powerful shippers who control industrial railroads. Some industrial concerns control tracks and terminal facilities actually owned by small railroads and connecting carriers, which make a switching allowance, or division of the joint rates to such terminal lines, which practice places the industrial corporations at an advantage amounting to concessions in the nature of rebates.

An inclustrial or manufacturing concern can not operate a railroad cheaper than a corporation exclusively engaged in transportation, but the control of the railroad by an inclustrial corporation gives a decided advantage over its own lines and the lines of its competitors. This assumption of industrial corporations to operate and control railroads deprives the public of fair treatment in shipping and has the effect of unjust discrimination. rikewise when industrial corporations obtain control of steamship lines and docks by means of which their raw material can be transported directly to the plants of the corporation, independent competition must suffer a serious hardship, all caused by the inequitable advantages which occur from the industrial control and operation of such lines for transportation. There can be no doubt that the ownership and operation of common carriers must result to considerable advantage when compared to other industrial concerns engaged in the same line of industry who do not own and control lines adaptable for the transportation of material necessary for the successful operation of their plants. It is also 
perceptible that such lines are being owned and operated purposely to obtain more than what ninight be called a due proportion of the division of the freight rates. Under industrial control and oper. ation the rates for transportation are usually excessive, affording at high per cent for returns upoil the investment. The pitblic has an interest and a right, no matter what are the costs, to have a reasonable rate for a particular service done. The measure of ralte is what the service is wrorth.

The maling of rates is done by agreement among the railroads to which agreements the industrial corporations are parties, and incidentally the bencficiaries of the high rates maintained by the controlled and operated lines. When hew rates are contemplated, the industrial corporations are generally represented at the conferences and the rates are made as high as the traffic will bear, which always proves profitable by the favorable division of the.rates, In unreasonable and highly profitable charge is made upon raw material by comnion carriers to the extent that the industrial corporations are indirectly benefited by reason of tise ownership of the lines when they transport their own materials to their own plants and when they transport freight to the connecting carrier for shiment. Again, the rates for transportation by steamship lines and the service of dock companies yield profits that are not only excessive but grossly out of all proportion to the actual cost of conducting the business for a fair return upon the value of the property utilized. The benefits dite to the ownership and operation of these transportation lines are clearly represented in the carnings of the corporations and can easily be traced through their authentic annual reports showing all their expenses and reventes until they finally reach the balance of profits and declared rate of clivicleinl. In some instances the returns or profits for carriage have been most exorbitant, ranging from 40 to nearly 400 per cent. Uncler a lease control the industrial corporation receives the entire proceeds, excepting the small rate of interest payable on the shares held by the stockholders of the leasing corporation, and frequently the rate of intcrest on the shares of stock is stipulated in the terms of the lease sufficiently low to guarantee a high per cerit of income to the lessee. As illustrating this feature of mainipinlation reference may be made to the Bessemer \& Lake Erie Railroad Company, which owns 8.87 miles of railroad, a line which was constructed to shorten an angle 
in the Pittsburg, Bessemer \& Lake Erie Railroad, containing 2I3.4I miles of track, and controlled under lease by the Bessemer \& Lake Erie Company, capitalized at \$500,000.

The report of the Bessemer \& Lake Erie Railroad shows a capital stock of $\$ 500,000$; a net corporate income for the year encled June 30 , I9I2, of $\$ 1,936,804$, or 387.36 per cent on the capital stock; dividends declared from the surplus were 250 per cent; balance credit Profit and Loss, June 30 , I9I2 (undistributed surplus), \$2,413,60I, or 482.72 per cent. The Duluth, Missabe \& Northern Railway Company has a capital stock of $\$ 4, \mathrm{II} 2,500$, and a net corporate income for the year ended June 30, r912, of $\$ 2,766,06 \mathrm{I}$, or 67.26 per cent; dividends declared from the surplus at roo per cent; balance credit Profit and Loss, June $3^{\circ}$, I9I2 (undistributed sumplus), $\$ 4,581,017$, or III.39 per cent. The Duluth \& Iron Range Railroad has a capital stocls of $\$ 3,000$,ooo; net corporate income for the year ended June 30 , I9I2, $\$ 2,578,232$, or 85.93 per cent; dividends declared from surplus were go per cent; balance credit Profit and Loss, June 30, I9r2 (undivided surplus), \$2.216,39I, or 73.88 per cent.

Allowances out of the rates on all shipments outbound and inbound from the plants in some instances anount to a very stibstantial part of the rate. Rate divisions on the raw materials are often far in excess of what Fecleral investigation has said is a fair compensation, and much greater than the proportion of rate received by railroad owned terminals for a similar and identical servicc. Derices and practices are instituted which may not all be strictly in violation of the Act to Regtilate Commerce; nevertheless, they result in unfair arlvantages to the inclepenclent industrial corporation. Records of terminal lines owned by inclustrial corporations show that the business transportation is mostly the carriage for the industrial corporations owning them, whereby an immense revenue is derived for the handling of their own freight. This gives an income out of all proportion to the cost of service, being regulated by agreement for the division of the rates. Terminal allowances arc arbitrary sums, usually so much per ton, or car, paid to the railroad handling the freight at the point to which it was originally consigned. The switches, connection and rolling stock are incorporated as a common carrier and used entirely for the transportation of their own freight. Such switching railroads are aptly called plant facilities by reason of their function to facilitate the delivery or assembling of raw 
materials to the plants operating them. These switching roads connect with large trunk lines and the shipper, having the routing of immense tonnage, meaning vast sums of money to the carriers, can by means of the routing device play one road against the other, and thereby obtain an inequitable division of the joint rates, (which are in effect purely rebates and excessive allowances per ton, or car,) in such amounts as to render the corporations responsible for the advantage over the other industries which have no such devices for the evasion of the law, or for preventing the unjust discrimination in making freight rates.

The officials of large trunk lines are not willing parties to these devices, but they are either induced by self-interest or compelled by the fear of loss of traffic to concede advantages to industriaf corporations that are the originators of tremendous tonnage of freight. Railroads, both large and small, seek these favors and. will gladly turn switching and transfer business to the indtistrial! corporations in the hope of receiving the transportation business. in return. By the power to route shipments of their own freight over their connecting lines they are able to dictate the division of the rates to the trunk lines making the long haul. Such practices have been endured by the privately owned railroads in the controt of the blood-fed monopolies. Nearly all the great trunk lines have been interested in industries where freight was a large elcment in the cost of marketing a great bulky product. Wherever the industrial corporation is both the shipper and the carrier, the higher the rate the greater its profits; and since freight rates are never established, but actually arranged by the conferences between all the railroads in a given territory, the representatives of the railroads owned by the industrial corporations will alway:wield their moral infuence and vote in favor of the highest rate obtainable, which always means a rate just as high as the traffic will bear. Investigation has shown that the policy of the United States Steel Corporation in the matter of freight rates has been to insist upon a rate just as high as it can be, if the railroads will give some definite rebate, or preference in some other way; meaning that the return for the favors should be a large proportion of the division of the rates for freight routed over the large trunk lines. The tendency of the railroads to favor these industriaf corporations becomes manifest when we realize that the railroads purchase about 40 per cent of all the steel manufactured in the United States; and it is not in human nature that directors of 
an industrial corporation like the United States Steel Corporation, selling its millions of dollars' worth of steel in the way of structural steel, rails, etc., to themselves as directors of the railroads, should do otherwise than favor their own corporation. Under these circumstances it is not surprising that the price of steel rails exclusively consumed by railroads should remain fixed for a period of ten years at the arbitrary price of $\$ 28$ a ton.

The evil effect of the control and operation of common carriers by industrial corporations cannot be denied. Complaint has been made to the Interstate Commerce Commision by parties engaged in the shipping of independent products. The commission has justly complained of the great difficulty in solving these intricate questions and permitting the continued injustice which arises from the cunning manipulation of terminal allowance and the division of the joint rates. Neither is the evil cured by the decisions under the "commodity clause" of the Act to Regulate Commerce, although the legislators aimed directly at this evil system of allied transportation by declaring that "it shall be unlawful for any railroad to transport in interstate commerce *** any article, or commodity, other than timber and manufactured products thereof, wherein it has an interest direct or indirect." The commodity clause was held valid by the Supreme Court in the case of the United States i'. Delaware \& Hudson Company. 213 U. S., 366. As the Court construed the clause, however, the bona fide ownership by a carrier of stock in a producing company does not constitute a direct or indirect legal interest in the carrier in the commodity manufactured, mined or produced within the meaning of the act. (Justice Harlan dissenting.) In this case it was also decided that a company organized as a canal companyand only operating a railroad as an incident to mining, was subject to the act as to its interstate commerce. It is perhaps a fair inference from these cases that while a railroad company may own stock in a mining company, it can not use such ownership for the control of such subsidiary company without falling within the prohibition of the act. The result is that the commodity clause is aimed at only one feature of the proposition, when in fact it should have double significance and application not only to prohibit railroads from owning industrial corporations engaging in interstate commerce, but likewise to prohibit industrial corporations from owning and operating railroads. 
By inrestigation it has been ascertained that the power and profits of the United States Steel Corporation rest in its ownership and operation of common carriers. The recent investigation by Congress of the United States Steel Corporation shows that the actual cost of production of the Steel Corporation and of other large independent concerns is nearly the same; yet the profits of the Steel Corporation infinitely exceed those of its competitors. No doubt the difference between these profits is in the main obtained by advantageous freight rates for transportation. This, in fact, was admitted by Judge Gary before the Committee when he expressed the opinion that the Steel Corporation could cut down prices sufficiently to drive many of their competitors out of the business. This is so not entirely because of its hold on the markct, but because of its ability to produce more cheaply and because of its ownership in the independent concerns, such as the railroads, the steamship lines and dock facilities, which give a large credit from the United States Steel Corporation's standpoint; showing that transportation lines, in Mr. Gary's opinion, are the important factors, and if the Steel Corporation chose to do it, with its present weapons it could actually destroy its competitors. So as long as great industrial corporations are permitted to organize a system of switches, located entirely on their property, into a corporation on equality with common carriers, these abuses arising from the division of joint rates and terminal allowances to actual plant facilities can never be adequately relieved. An industrial corporation transporting its freight for a few miles over its own lines by means of its own facilities should be required to place its freight into the course of commerce on an equality with that of an ordinary shipper tendering a single car of similar material for shipment. If there is any special reason why an inclustrial corporation should control a railroad, the benefit which comes to the industry by reason of such economy will be sufficient without making it allowances for terminal services, or divisions of joint rates with the regular common carriers.

It is apparent that the opinion of Congress, when debating on the Hepburn bill for the prevention of discriminations, which is the very essence of the Act to Regulate Commerce, was that sound public policy demands the divorce of production, manufacture and ownership of property from transportation of that property. Also when the commodity clause was discussedl. 
Senator Elkins said that the purpose of this amendment was to make a start towards divorcing production from transportation. Both in the Senate and in the House the debate conclusively showed that Congress had in mind that these evils existed from the excessive allowances made to the transportation lines by industrial operations, and that this undue discrimination could only be avoided by a complete divorce of the ownership, or production, from the transportation of property.

The debate on the Hepburn bill throughout, both in the House and in the Senate, shows conclusively that it was in the mind of (ongress that great evils existed from the aflowance to shippers of cxcessive amounts for transportation facilities furnished by them, and that undue discrimination could only be avoided by the complete divorce of the ownership, or production, from the transportation of property. We shall cite only a few instances which we think establish conclusively the fact that in the opinion of Congress ownership, or production, should be divorced from transportation.

(n January 3I, xgo6, Representative Campbell, of Kansas, said (Congressional Record, Vol. 40, Part 2, p. 1828) :

"The irresistible result and the logical effect of conceding to large shippers the right to use their own facilities is the creation of monopoly, which is always dangerous to the public welfare."

And on February 2, I906, Mr. Goulden saixl (to Congressional Record, Part 2, p. 196I):

"The bill that passed last Congress, and against which I had the honor of casting my vote, was exccedingly objectionable. The provision creating a special court with its heavy expenses, the failure to reach the private-car and terminal-charge evils, caused the Senate to refuse last year to consider the action of this body. The thousands of private cars of the meat, fruit and other trusts dictated terms to the railroads and compelled compliance with their clemands."

And on February 7,1906 , Representative Wiley, of Alabama, repeated what he had said a year previously (Congressional Record, Vol. 4o, p. 224r):

"There are numerous business concerns in all sections of the country having several miles of private side tracks, switching privileges and terminal facilities. These accommodations, by whatever name called, enable the owners to secure special rates, which are but a stibterfuge, device or scheme to cover up and hide from 
the eyes of the public unjust rebates. They obtain a division of freight on all cars delivered to connecting roads by means of their private terminals, and receive compensation for service rendered which is unfair and excessive. These abuses can not be rectified until these terminal companies are placed under the control of the Interstate Commerce Commission."

On May 7, 1906, Senator Bailey said (Congressional Record Vol. 40, Part 7, p. 6460) :

"I had supposed that this is one correction upon which all Senators would agree, because I have not during this prolonged discussion heard any Senator express any opposition to the divorcebetween the business of a common carrier and the business of a miner, manufacturer or a producer."

And on May 8, 1906, Senator Aldridge said (Congressional Record, Vol. 40, Part 7, p. 6507):

"Mr. President, $I$ think there is a practical agreement in the Senate that the business of transportation by interstate carriers ought to be divorced from the business of production by the same carriers."

On March 13, 1906, Senator Simmons said (Congressional Record, Vol. 40, Part 4, p. 3727):

"It is a well-known fact that within this time certain combinations have monopolized many of the prime commodities of industry and commerce, and, through the enormous volume of business they can give or withhold, aided by the devices of private switches, cars, refrigeration, ventilation and icing, have for some time past compelled, and today in many instances compel the railroads to accept such compensation as they are willing to pay for the transportation of commodities in which they deal or for the traffic which they control."

As an administrative body, the Interstate Commerce Commission can not stop at the surface of a transportation problem because its form and outward appearance are regular, but must reach the actual situation and examine its real substance, and thus be able to enforce the prohibitions as well as the requirements of the act. The commission has said that the controlling inquiry should be, not the character of the servant which renders the service, but the character of the service rendered:-17 I. C. R., 5 54 -

When a plant facility performs a service clearly confined to the processes of manufacture, conversion and production, no one would contend that a carrier could legally assume any part of the 
expense of such service; but a plant facility service may in some cases have many of the physical incidents of a transportation service, and it is in connection with such cases that the difficulty, if there be any difficulty, arises. Unless a railroad is legally found to perform the service for which it proposes to make these allowances, the allowances can not lawfully be made by it, and the Commission has directly held that a railroad is not found to perform such services :-I4 I. C. R., 237 ; 20 I. C. R., 200.

III.

Twenty-two years ago, Congress passed the Sherman Anti-trust Law, forbiclding combination in restraint of trade. During this period the great industrial combinations, as the Sugar Trust, Beef Trust, Coal Trust, Steel Trust, Tobacco Trust, Oil Trust, Shoc Making 'Trust, Harvester Trust and Lumber Trust, have all developed and prospered and also clepressed business and oppressed the public. There have been seven prosecutions for violation of the Anti-trust Law under the Farrison Administration, eight under the Cleveland Administration, three under the MICKinley Administration, forty-four uncler the Roosevelt Administration, and nearly fifty under the Taft Administration. In a number of these suits, the decisions of the Courts have been in favor of the (iovernment in this period of prosecution; notably so in four cases-the Xorthern Securities case, the Stanclard Oil case, the Tobacco case and the Union Pacific MIerger case, with the Steel case and others pencling. Mr. Taft has done more in four years than all the other Presiclents combined, in office during the life of the Sherman Law. The defining of the rule of reason in the ()il and Tobacco decisions was first looked upon as a step backwards, but recent decisions and the adjustment of tracle conditions thereto have about demonstrated tout an contrairc.

The following passage in Presiclent Taft's message to Congress just prior to its acljournment for the holidays is worthy of especial consideration:

"A tracle commission which looks to the fixing of prices is inpractical and ought not for a moment to be considered as a possible solution. The enforcement of the Sherman Anti-trust Law is gradually solving itself, is maintaining the principle and restoring the practice of competition; and if the law is quietly but firmly enforced business will adjust itself to the statutory requirement and then the unrest in commercial circles provoked by the trust cliscussion will disappear." 
The Sherman Law had been believed by many to be vague and indefinite to such a degree that even the Courts could be led astray easily as to its exact meaning in its application to matters before them. Has the result of vigorous attempts to clestroy commercial competition been a failure, not less absclute, though not confessed? By the Sherman Anti-trust Law, the successful prosecution as criminals of men engaged in the attempt by criminal and barbaric methods to destroy competitors has been maclc possible. It has proved that great combinations are not above the law, and their crimes can be bronght to light and repetitions rendered impossible in the future. Transportation has been regulated and improred in quality, but the powers have not been fully employed. There must be a supervision of corporations by the Government. The over-valuation of properties and overissue of stocks and bonds must be prohibited. Labor conditions must be under control of the State Law.

The effect of the Sherman Iaw may be seen in the recent opinion of the Supreme court holding the Pacific merger illegal. Herein the combination was declared to be a violation of the Anti-trust Act, all brought about by the acquisition of stock shares designed to maniptilate sufficient control of the Southern Pacific by the Union Pacific to effect a consolidation of the two companies, and thereby stifle competition among common carriers and dominate interstate traffic. Concerning this merger the Court said: "In order to effectually conclude the operating force of the combination such disposition should be made subject to the approval and decree of the Court, and any plan for the disposition of this stock must be such as to effectually dissolve the unlawful combination thus created. The Court shall proceed, upon the presentation of any plan, to hear the Government and defendants, and may bring in any additional parties whose presence may be necessary to a final disposition of the stock in conformity to the views herein expressed."

The tendency of the Supreme Court to tighten the interpretation of the Sherman Anti-trust Act was manifested recently by the disapproval of the plan, or scheme, proposed by the Union Pacific Railroad attorneys for "clissolving" the Union Pacific-Southern Pacific Railroad merger by allowing the Union Pacific stockholders to have the exclusive privilege of buying the Southern Pacific stock now owned by the Union Pacific Corporation. The Union Pacific attorneys claimed for the stockholders this ex- 
clusive privilege of taking over the $\$ 25,000,000$ worth of Southern Pacific stock, "in order that they may have an opportunity to protect themselves against the sacrifice of this valuable asset covered by investment." The attorneys claimed that the so-called controlling interest in the Union Pacific held only ${ }^{3} 3$ per cent of the stock of the Union Pacific, and, therefore, would be able to buy only 6 per cent of the total capitalization of the Southern Pacific Company. This may be as they claim, but it is evident that Supreme Court are becoming very alert concerning "paper" dissolutions, and the decision is regarded as a highly" important precedent in anti-trust legislation. The Court took the position that a corporation is only another name for the stockholders, and to allow the Union Pacific stocliholders to buy the stock now held by the Union Pacific Railroad Company, the corporation of which they are stockholders, would amount to nothing effectual.

"In rejecting the proposal," saicl Justice Day, "for the transfer of the Southern Pacific Company's stock held for the Union Pacific Company, either by distribution among, or sale to, the stockholders of the Union Pacific Company, we do not mean to preclude the District Court from considering and acting upon the plans which may be submitted to it under the former opinion and clecree of the Court. We are of the opinion, however, and now hold that the proposed plan of disposition of the entire stock holding of the Union Pacific Company in the Southern Pacific Company by transfer will not so effectually end the combination as to comply with the decree heretofore ordered to be entered by the Court."

Plans for the disposition of the shares of stock proposed by the railroad officials have all been discarded by the AttorneyGencral as inconsistent with the demands of the Court decree. This action reveals the determination of the Government to view very critically and make effectual the plans for separation of interests into their integral parts. Surely this decree was one of the most far-reaching opinions ever rendered by the Supreme Court, and henceforth the results of decrees for dissolution of monopolies existing in violation of the Sherman Anti-trust Act will be made more complete, and inter-corporate directorates will be conclusively prohibited. There has been no regulation by way of amendment to the Sherman Anti-trust Act of July, I89o, although many eminent men have said that it should have been repealed 
in toto. Eminent men doubted the justice and soundness of the decisions in the Standard Oil and Tobacco cases, but probably since the later decisions those who doubted the majesty of the law are more convinced that the Courts are able to control and break up the goaded monopolies and put an end to the existence of corporations which are chartered by the States, and which have shown themselves harmful to the public. It has demonstrated and established the power of the Govermment over corporations and combinations organized with unlimited power by State authority. With these decisions against monopoly the Iiederal power is defined, without which subsequcnt regulation could not be made effective by passing more laws until the Govermment had clemonstrated its power to enforce those laws previously enacted. These decisions have ended numerous unfair methods designed to crush and destroy competition: the holding company was severed; the subsidiary companies were separated and prohibited to be managed as a harmonious unit; publicity of corporate affairs, which appears to be the greatest protection against aggregated corporate abuse and oppression, was enforced.

There are now 270,000 corporations in the Linited States whose income is in excess of $\$ 5,000$ annually, subject to the Corporate Tax Law. These have an aggregate capital stock of fifty-seven billion dollars, bonded indebtedness of thirty-two billions and an aggregate net income of three and one-half billion dollars. The enormity of controlling interests may be conceived by the result disclosed by the congressional investigation that eighteen corporations whose interlocking of directors gives them domination of the financial field are so inter-related to each other that an exact estimate of their dependence is hard to make. The "capitalization" attributed by the committee's experts to each of these eighteen firms refers to the total capital stock and funded clebts of the various corporations "interlocked" with the financial institution. The $\$ 25,325,000,000$ total of control fixed by the experts represents the total of control exercised by all of the eighteen firms acting together.

These eighteen firms have only 180 members, who hold directorships in I24 of the wealthiest corporations of the nation. The statistics showed that those 180 men have 385 directorships in $4 \mathrm{I}$ great banks and trust companies, with aggregate resources of $\$ 3, \$_{32}, 000,000$; 50 directorships in I I giant insurance companies with assets of $\$ 2,646,000,000$; I 55 directorships in 31 great 
railroad systems capitalized at $\$ 12,193,000,000 ;$ six directorships in two express companies and four directorships in one steamship company with a combined capital of $\$ 245,000,000$ and a gross income of $\$ 97,000,000$; 98 directorships in 28 industrial corporations capitalized at $\$ 3,583,000,000$ and earning over $\$ \mathrm{I}, \mathrm{I} 45,000$,$\infty 00$ annually; and 48 directorships in 19 public utility corporations capitalized at $\$ 2,826,000,000$, and earning over $\$ 428,000,000$ annually. Transportation companies in whose board of directors Morgan representatives sit, were said to be: International Mercantile Marine Company ; Adams Express Company; Atchison, Topeka \& Sante Fe; Chicago Great Western; Erie; Lehigh Valley; New York Central; New York, New Haven \& Hartford; Northern Pacific; Pere Marquette; Reading; and Southern.

The investigation of the Steel Corporation by the House Committee disclosed-most astounding facts and conclusively showed that the United States Steel Corporation was purposely organized under the liberal corporation laws of the State of New Jersey as a holding corporation in character designed to monopolize the steel industry of the country. It was incorporated in April, I90I, with about $\$ 1,400,000,000$ of capital, of which approximately $\$ 600,000,000$ to $\$ 700,000,000$ was water, being greatly over-capitalized. This, however, has been remedied to a great degree by extensive investments of earnings since its organization. The objects aimed at by the organization were: greater integration and the consequent increased economy and efficiency in operation and the avoidance of paying profits to outsiclers; promotion and stock market profits ; and lessening of severe competition in business. The earnings of the Steel Corporation for the decacle from IgOr to IgI I averaged about 12 per cent annually on the actual value of the property. The output for rgor was about 42 per cent of the total output of pig iron in the United States, and in I9Io about 43 per cent. In I9OI the Steel Corporation produced about 60 per cent of all the crude and finished product of the United States. By IOII its percentage of the product dropped to 50 per cent.

The directors of the United States Steel Corporation are men of wealth, having great business ability and large interests, which command fabulous wealth sufficient to dominate financial and inclustrial and transportation affairs. Their experience and ability have been largely utilized by the companies with which they are connected. They are nearly all directors in other companies 
than the United States Steel Corporation. These companies are of various kinds and include railroads, banks, and manufacturing companies. No evidence was given or offered tending to show that the fact of such relations, on the part of the directors of the United States Steel Corporation, had ever been used or attempted to be usecl to the injury of competitors, to obtain any unfair advantage for the United States Steel Corporation, or to the detriment of the general public. In every instance the directors of the United States Steel Corporation constitute only a very small minority of the directors of the other companies with which they are connected. Such relations, however, give opportunity for abuses and agreements in restraint of trade.

The system of interlocking directorates employed had insidious consequences which no man can gauge. Yet that evil is not so great today as it was five years since. "Inside management" is a term used to express a certain reprehensible practice which a few years ago was all too prevalent in the business world. When, in administering the affairs of any corporation, the directors pursue a policy more favorable to their own financial interests than to those of the corporation which they are chosen to representto characterize such practices men use the expression, "insicle management."

Interlocking directorates facilitate "inside management." Interlocking directorates often have been used for the purpose of stifling competition. Yet in many communities it is a distinct advantage not to limit the sphere of usefulness of any business man. Interlocking directorates, like so many other human agencies, are fit subjects for regulation rather than for destruction, and doubt is expressed as to absolute prohibition, unless regulation shall fail to abate the evil.

In some instances stocks were not "watered" in the ordinary acceptance of the term; they were literally deluged. The cost of constructing or reproducing the several plants constituting the combine was inconsequential as compared with the value of this new device for enjoying with immunity an old and hitherto forbidden privilege-an absolute monopoly in a valuable and necessary article of commerce. It had, at the beginning, secured the consolidation of a great number of steel and iron works, big and little, modern and antiquated, not only with a view to scientific and economical co-ordination of plants and processes, but to the curtailing of production and fixing prices. These mines, mills, 
and furnaces, thrown together in a hurried and haphazard manner, had been capitalized at approximately 300 per cent of their actual yalue, and weighted and trammeled by this burden of excessive capitalization, they were confessedly unable to meet impending competition from one single concern, until recently a limited partnership, which had avoided the evils of the stock exchange and the control of the syndicate.

The extent to which fictitious yalues have been created by overcapitalization of corporate property has shaken public conficlence in corporate securities and made the public mind distrustful of large business entepprises. This policy has cheated both the investor and the consumer. The investor has purchased stock under the mistaken belief that the face had some relation to the value. The consumer of corporate products has come to feel, and with much justification, that he has been made to pay exorbitant profits to over-capitalized corporations that they might pay dividends on fictitious stock yalues. The faijlure to pay dividends meant a depression of its stock and a disturbance of the stock market, and the interests in control had a greater interest in and derived a greater profit from their operations in the stock market than from the manufacture of steel.

Undoubtedly the question which most deeply interests the American pegple, in regard to the United States Steel Corpora= tion, is what effect it has had upon the prices of ifon and steel products which are furnished to the people of the United States. If it has had the effect, either through inefficiency or otherwise, of increasing the cost to the public of the kind of products it manufactures, it is to be condemned upon economic grounds. If it has produced such an effect through illegal combinations, it is to be further condemned as a violator of the law. Of course no

- one can be certain what the prices of steel products would have been if the United States Steel Corporation had not been organized, and therefore no one ean prove with absglute certainty that the United States Steel Corporation has lowered prices beyond what they would have been if it had not been organized; but, on the other hand, those who seek to show that it has a tendency to increase prices will find little consolation in the facts ascertained by the committee. It is undoubtedly true that the corporation has a steadying effect upon prices and prevented wide fluctuations. The tendency of prices has been downward, and prices are probably lower than they would have been had the company never existed. 
It has been said by notable gentlemen before the Senate Committee of Interstate Commerce that the present Anti-trust Act should remain in the statute books unaltered and unchanged; that an attempt to define by statute the phraseology of the act would not be a step in the right direction. It would lead to greater uncertainty and lead to a great deal of litigation. Congress should defer any modification of the language of the act until we have had some further decisions by the Supreme Court showing that the results desired by Congress will not be attained under the present law. Public interest would be best promoted if at the present session of Congress some legislation should be undertaken in the regulation of Industrial Interstate Commerce. A question arises in the probable event of legislation if any change could be made in the Sherman Law that would improve it materially, considering the twenty-two years of experience.

IV.

It is wiser to keep the administration of laws in the hands of qur executive officer whom Congress should hold responsible, and who, with his corps of assistants, can act instantly to meet all emergencies and contingencies, and in no instance should there be a divided council. There is nothing inherent in the organization, in the form of the organization of the Department of Justice that should impede the proper and thorough enforcement of laws. The progress is sometimes clogged by influence, as it sometimes happens in our large cities like New York and Chicago, that the laws against gambling and other forms of vice and criminality are not so well enforced as they should be, because of the influence of the organized power of money. The power of millions and billions often finds it possible to hobble the enforcement of law and impede the administration of justice. These combinations aiming to restrict the administration of justice, naturally hobble everything for a degree of time, although it is inevitable that their power would soon be reduced to a fraction if brave and fearless Government officials would exercise exhaustive resources to enforce the law against this terrible and menacing oppression. The law against smuggling is thoroughly enforced by the Department of Justice, also the law against counterfeiting and illicit distilling. The Department of Justice is not weak in organization, but it needs further encouragement and support. If these officers should fail in their duty against revengeful trusts, 
they should be relieved of duty, and courageous men put in their places, who, fearless of monopolistic power when armed with the law, would know nothing but tireless prosecution.

There is a fraction of truth that the great trusts and monopolies in this great country today originated largely through favoritism in the way of rebates, and rates, and special privileges, extended to them by the private corporations which controlled the railroads. If there are any great trusts or aggregations of capital receiving any special favors to enable them to crush out competition and control the market, the present laws do not provide a proper remedy for the evil; but if there are sufficient and adequate remedies for the evil, some reason must exist for ineffective laws. One reason seems clear, and that is that the Government fails through the executive branch to properly enforce the law. The great mass of the people today believes that the principal difficulty, the principal evil suffered from these great aggregations of capital known as trusts, arises from their ability to defy the law and escape its provisions and penalties. A popular remedy might be a change of fine to a cruel Draconion law, to punish the men who violate the Sherman Anti-trust Law by providing not less than two years nor more than ten years in the penitentiary for these officers. Apparently these officers of trusts are well known, because they can not be hidden from the public eye, and it is visible to every one that much indignation has been aroused by the wholesale defiance of the law and neglect of the executive officers of the Government to properly punish or proceed against those violators.

Every citizen has felt the hand of oppression from the operation of the Beef Trust, the Oil Trust, the Steel Trust, the Tobacco Trust, and others of that character. In the face of prosecutions, the people are subjected to excessive prices unexplainable. President Taft, in his Chicago speech, said that the business men complained that they were unable to understand just when they were violating and when they were not violating the Anti-trust Act. The belief is that such business men who protest are extremely innocent, or intentionally deceptive, because the President cloubted the soundness of their contention; and that any jury could tell in two minutes whether a man intended to establish a monopoly, or a corporation. Very few of these business men have been brought before a jury to try whether they are guilty or innocent, and when there was a late attempt to bring 
them before a jury they were so sure of their innocence that they resorted to the extraordinary proceedings of habeas corpus to avoid facing the jury. Should not the criminal provision of the law be fully enforced against them? . But it seems that during the last twenty-two years the civil provisions are far too drastic without going to the criminal provision that the attorney-general has been afraid to invoke against them. Just why this is a fact no doubt the general public would be much pleased to learn from the Department of Justice itself, 一why it is afraid to invoke a provision inserted in the civil clause of the law from fear of which the giant, seasoned, rhinoceros-lided corporations, like the Standard Oil and the Tobacco Trusts, become tender.

The primary purpose of legislation, whether State or Fedieral, is, first, to restore to the individual citizen, or the smaller aggregations of actual capital, an opportunity to engage successfully in commercial business, and second, to reduce for the consumer the exorbitant price of commodities produced by the present combinations or cognomened trusts. Under present conditions, it is impossible for an individual to engage in business, or a corporation established in business to know whether it is violating the Anti-trust Law until it has been proceeded against by the Federal Government. No doubt agreements can be entered into clearly in restraint of trade and in violation of the Sherman Anti-trust Law, but it is impossible to actually know, by virtue of its size and character of its business, whether or not a corporation is violating the law until Federal prosecution is begun, because it would be largely a matter of opinion and judgment as to its actual status. There is not a definite rule to determine what per cent of the manufactured product makes such corporation a trust under the law. Resort to the Courts is necessary now to overcome restraints of trade, but many are of the opinion that some remedy should be devised which should be self-executing, of an administrative nature in.contradistinction to legal procedure, which is unsatisfactory to Governments. A corporation receives a privilege from the State Government to capitalize its business. The right to associate capital under one control is a valuable right, and the Government apparently has a right to demand something in return for the corporate privilege extended.

It will at length come to be generally understood that interstate commerce is not static, but active; not a condition, but a movement. There is a wide difference in fact, but none in law, 
between the man who engages in a few small interstate transactions each year and the corporation engaging to the extent of hundreds of millions a year. There is a doctrine which has been adopted by the Courts to reconcile the difficulties of having two forms of law,-laws made by the State and laws made by the United States,-which doctrine says that the States shall have the power where they have no purpose of regulating interstate trade, but intend to carry out some legal purpose that is proper and within their jurisdiction, of passing laws even though they may have a direct or remote or unintended effect on interstate or foreign commerce. Both the States and the United States are to some extent engaging in interstate commerce. But that is not the fact with which the Federal Government is concerned in regulating interstate commerce. Congress may punish, enjoin, and otherwise deal with individuals, through Court process, as an incident to the regulation of commerce. But that all pertains to the remedial or administrative branch of its power, and is referable to another provision of the Constitution. Primarily, the power to regulate the conduct of individuals and corporations is in the States, and pertains to the police power. Legal procedure may amend one evil by prosecution, if forcefully applied, against the trusts or combinations in the form of the monopoly. Also where the wrong is perpetrated should be the place of trial, just as in the prosecution of crimes. When States made corporations a vital power to act and conduct business as persons, then the evil began to develop with alarming rapidity. Although limited in capacity for a time, they later combined and extended their operations into other States, and then problems developed with endless complications. They could not be held within the bounds of their corporate charters from which they gradually broke and thus placed themselves in the domain of the Federal Government, inviting Federal regulation. How to prevent oppression; how to fix liability; how to insure honest management; how to prevent hurtful over-capitalization; how to prevent aggregations hurtful to commerce; and how to separate the carrier from the manufacturer, have all become questions for solution by the National Government. All are objects of interstate commerce and subject to regulation under the Constitution. The Constitution is not a command of divine origin, everlasting and unchangeable, nor is it a code of laws, but rather a declaration of principles intended to be applied to the changing conditions of the growth of the nation 
and society in general. A liberal construction of the Constitution has been maintained by the Courts of the country for a supremacy of national power, first instituted by Justice Marshall, who gave the Constitution its most progressive and elastic construction. The power of the National Government to control corporations engaged in interstate commerce by a system of licenses or incorporation acts is fully sustained by the opinion of the great Chief Justice. All authorities agree that Congress has plenary power to provicle regulations under which it can permit corporations organized under the laws of the various States to engage in interstate commerce. The National Government may correct the very evils which the unlimited corporation laws of many of the States permit. The National Government may regulate the amount of capital; may regulate stockholding in other corporations; may regulate all attempts to monopolize; and may regulate any unfair methods of competition. Also the National Government may prevent these corporations from engaging in interstate commerce if they violate the regulations enacted.

This is an age of centralization, which no broad-thinking man can doubt. By improved means of transportation and communication this country is a unit which was wholly inconceivable at the time the Government was founded. State lines have vanished in commerce and transportation affairs. Surely it is iclle legislation to attempt to resist these unifying influences which dominate and operate in every section. We must have concentration and coöperation in Government regulation for commercial advancement. Concentration and coöperation are conditions imperatively essential for modern industrial advance. The people universally demand it and industry will decline from a high efficiency standard if concentration and coöperation are ignored. Obsolete laws must be modified and new legislation enacted to control and regulate. The doctrines of political economists must be ignored because conditions are ruming counter to all history. In this century combinations international in scope have by the immense preponderance of power clistorted the operation of all general economic laws. Some kind of legislation is necessary to correct evil in the development of monopoly which the State cannot reach until the monopoly has arrived at maturity and caused no end of distress. Such legislation should be a method of restraint designed to crimp the symptoms of malevolence. Specific statutes are needed as initial safeguards to restrain over-capitalized 
concerns exercising the power of a holding company from entering or continuing in the field of interstate commerce. Whatever is done affecting this great aggregation of capital should be only after great deliberation and nothing should be done hastily. The landmarks of our Government and the principles of government should be closely observed in this prospective legislation affecting so great a subject. Freedom and equality are the prime purposes of our Government, and whatever legislation is pending should have these principles foremost in mind and be directed to that encl.

Some comment is aimed at the proposed bill, which contains a fundamental fault manifest throughout that it strikes at the size of industrial corporations; that it preserves the chief fault of the Sherman Law, which is the policy of a belated attack after the monopoly has reached the stage of maturity, instead of provicling some means of prevention during development. Neither does the bill provide for an agency to insist upon the enforcement of the safeguards. Some think that the element of size is not an integral of danger, but it seems that a corporation or monopoly can reach such large dimensions of business as to make its management impossible. That the size is inconsequential to a virulent monopoly is disputed. Certainly it seems manifest that the size is dangerous and uncontrollable by reason of its stupendous physical character and enormity of business. So staggering has become the New York, New Haven \& Hartford Railroad that the Federal Government has instituted suit for its dissolution into integral parts now controlled, which may be released from the present management to be placed under direct and efficient management. The size of this blooded monopoly is the evil which may be fully disclosed by the investigation of this railroad and its inside associations with the Canadian Grand Trunk. The question in industrial regulation is greater than the simple destiny of the United States Steel Corporation, and much more far-reaching than a simple acknowleclgment or criticism of its bad faults. That the solution of the question of the regulation of industrial corporations is a most difficult task, can not be denied. The legislators defining the Government's attitude toward industrial corporations must be certain which policy will insure respect for its authority and create and maintain stability in legitimate business. Such statutes should provide for supervision of all issues of securities, and prohibit one corporation from holding stock in another, and limit the extent to which two or more corporations may have 
common directorates. For the purpose of amassing capital, individuals are taking advantage of the liberal incorporation laws of the various States and have combined these corporations into vast aggregations to control wealth through interlocking clirectorate management. A single inclividual can not monopolize nor control the industries of this country unless he obtains a monopoly by special privilege. In this age enormous wealth is a necessary element for the development of industries, and such enormous wealth can only be massed by a combination of corporations who have no natural rights, being creatures of the Government. No great amount of good can result to the people by permitting a few privileged corporations to control all the industries. What is needed is strict Government regulation of industrial wealth, which makes a nation great by affording opportunities for every one who possesses a reasonable capital and ability to embark safely in some industry.

Thus, after reviewing the evils of special privilege and being fully convinced that some kind of governmental regulation is necessary to cure the damages caused by the ill-used unlimited power authorized by States, we are of the opinion that a Federal Incorporation Law would be in order for large corporations.

That the Sherman Act needs no revision, or strengthening, for the dissolution of the blooded trusts, but we recommend that the Federal Courts shall have exclusive powers in enforcing the Sherman Anti-trust provisions, to insure the thoroughness and completeness of their destruction. In view of the probable fact that the solution of the trust evils can not be obtained otherwise than by new legislation, some bills should be outlined to prohibit the interlocking of directorates, except when approved by an administrative industrial commission; and prohibit persons engaged in the manufacture and sale of railroad material and rolling stock, or in the mining and sale of coal, from becoming directors or other officers of railroads engaged in interstate commerce.

That holding companies should be forbidden except when licensed for temporary purposes of organization by an administrative industrial commission.

That all corporations, or combinations of some certain fixed valuation, should be compelled to acquire a United States charter before engaging in interstate commerce.

That all corporations, when they obtain a Federal charter, shall be required to reincorporate at an amount not to exceed the actual 
value of their assets. In arriving at the valuation of assets nothing shall be received for a "monopoly" value, or value merely for their exclusive or substantial control of the industry in which the corporation is engaged.

That incorporations interested in the arbitrary employment of members of industrial associations, as the American Fecleration of Labor and its subsidiaries, should be controlled by an administrative industrial commission.

That a company, firm, or corporation, or officer thereof, cloing a manufacturing business, directly or indirectly, should be prohibited to own in whole, or in part, directly or indirectly, by stock ownership, or otherwise, any railroad or ather transportation lines, or property of any common carrier.

That individuals, or a State, should have the opportunity to intervene in a Government suit, and access to the Courts, and the benefit of adequate and sufficient remedies for any wrongs sufferecl.

District of Columbia Bar. 